\title{
The novel concepts and practices of firm innovativeness: the mediating and moderating impacts
}

\author{
Abang Azlan Mohamad* \\ Faculty of Economics and Business, \\ Universiti Malaysia Sarawak, \\ 94300 Kota Samarahan, Sarawak, Malaysia \\ Email: maazlan@unimas.my \\ *Corresponding author

\section{T. Ramayah} \\ School of Management, \\ Universiti Sains Malaysia, \\ Minden, 11800 Penang, Malaysia \\ and \\ UTM International Business School (UTM-IBS), \\ Universiti Teknologi Malaysia Kuala Lumpur, \\ Level 10, Menara Razak, \\ Jalan Sultan Yahya Petra (Jalan Semarak), \\ 54100 Kuala Lumpur, Malaysia \\ Email: ramayah@usm.my
}

\section{May Chiun Lo}

Faculty of Economics and Business, Universiti Malaysia Sarawak, 94300 Kota Samarahan, Sarawak, Malaysia Email: mclo@unimas.my

\begin{abstract}
The objective of this study is to propose a conceptual model that blends the dimensions of knowledge management, information technology capability, innovative culture and firm innovativeness into a single framework for practitioners and academicians. In conceptualising the model, this study reviewed a range of existing literature. The findings identified: 1) four processes of knowledge management that represents the construct; 2) information technology capability as a variable that mediates the relationship between knowledge management and firm innovativeness; 3) innovative culture as a variable that moderates the link between knowledge management and information technology capability. The resulting conceptualisation is meant for evaluating the potential strategic model for firms to implement information technology capability and innovative culture. It is posited that the proposed conceptual model, when implemented, would enable practitioners a better understanding on factors that enhance firm innovativeness.
\end{abstract}


Keywords: knowledge management; innovative culture; firm innovativeness; information technology capability.

Reference to this paper should be made as follows: Mohamad, A.A., Ramayah, T. and Lo, M.C. (xxxx) 'The novel concepts and practices of firm innovativeness: the mediating and moderating impacts', J. International Business and Entrepreneurship Development, Vol. X, No. Y, pp.xxx-xxx.

Biographical notes: Abang Azlan Mohamad is a Senior Lecturer with the Faculty of Economics and Business, Universiti Malaysia Sarawak. He is in his final stages of his $\mathrm{PhD}$ programme at the Universiti Sains Malaysia. His research interests are in the areas of knowledge management, innovation, and organisational performance.

T Ramayah is currently a Professor in the School of Management at the Universiti Sains Malaysia. His publications have appeared in Journal of Environmental Management, Technovation, Computers in Human Behaviour, Resources, Conservation and Recycling, International Journal of Information Technology and Decision Making, and Journal of Business Ethics. He is constantly invited to serve on the editorial boards and program committees of many international journals and conferences of repute. His full profile can be accessed on http://www.ramayah.com.

May Chiun Lo is a Professor with the Faculty of Economics and Business, Universiti Malaysia Sarawak and Director of the Research and Innovation Management Centre, Universiti Malaysia Sarawak. She graduated with First Class Honours in Finance from the Universiti Kebangsaan Malaysia. She received her Master of Business Administration from the Herriot-Watt University, UK, while her $\mathrm{PhD}$ in Organisational Behaviour was awarded by Universiti Sains Malaysia. Her areas of expertise include corporate leadership, strategic management, entrepreneurship, banking, financial management and tourism management. She has published more than 140 papers with many high-impact journals.

\section{Introduction}

The contemporary world of business is highly competitive as a result of the dynamic nature of the marketplace. In facing challenging business competition, it is imperative for organisations to be innovative as these sets the firms apart from competitors. Wang and Wang (2012) elucidate that innovation is the primary source that enable firms to create superior value and attain competitive advantage (Subramaniam and Youndt, 2005) while Kim et al. (2015) suggest that admirable organisations practice innovativeness regularly in their response to adverse market environment. Baker et al. (2015) propose that the supreme task for firms is to innovate consistently while concurrently maintaining growth of sales. Furthermore, it is vital for organisations to continuously innovate to guarantee their survival in the market and to equip themselves with unique knowledge by converting knowledge into innovative resources to better their competitors (Cho and Korte, 2014). 